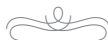 \\ ILLUSTRRATIONS
}

\section{IN THE TEXT}

p. 10 'Bending a Sail to a Yard'. From Darcy Lever, The Young Sea Officer's Sheet Anchor (1811).

p. 25 Sea-Faring Men, by John Glover (1767-1849). Yale Center for British Art, Paul Mellon Collection.

p. 49 Gustavus Vassa, by Daniel Orme after W. Denton, 1789. National Maritime Museum, Greenwich, London, Michael Graham-Stewart Slavery Collection.

p. 61 'Saturday Night at Sea', by George Cruikshank, 1841. From Thomas Dibdin, Songs, Naval and National, of the Late Charles Dibdin: With a Memoir and Addenda (1841).

p. 84 Woman of Eaoo, by Robert Bénard after John Webber. Fondo Antiguo de la Biblioteca de la Universidad de Sevilla/CC-BY-2.0.

p. 101 Study of Sailors Raising a Flag for the Victory of Lord Duncan, by John Singleton Copley (1738-1815). Yale Center for British Art, Paul Mellon Collection.

p. 114 The Slave Trade, by John Raphael Smith, 1791. Yale Center for British Art, Paul Mellon Collection.

p. 128 Sailors Carousing, by George Cruikshank, 1825.

p. 151 A View of Sydney Cove, New South Wales, by Francis Jukes, c.1804. Yale Center for British Art, Paul Mellon Collection.

p. 169 Part of the Crew of H.M.S. Guardian, by Robert Dodd, c.1795. Yale Center for British Art, Paul Mellon Collection.

p. 192 The Liberty of the Subject, by James Gillray, 1779. National Maritime Museum, Greenwich, London. 
p. 209 Sailors on a Cruise, by George Cruikshank, 1825. National Maritime Museum, Greenwich, London.

p. 239 Portsmouth, Hampshire, by W. Miller after Joseph Mallord William Turner, 1825.

p. 257 Richard Parker. LC-DIG-pga-12550 DLC/Library of Congress Prints and Photographs Division Washington, D.C.

p. 280 John Crawford, Nailing the Flag to the Main Top Gallant Mast Head, on Board the Venerable, October 11th 1797, by H. S. Kirby, 1804. National Maritime Museum, Greenwich, London.

p. 292 'John Nichol', by William Home Lizars. From John Nicol, The Life and Adventures of John Nichol, Mariner (1822).

p. 305 British Plenty, by Charles Knight, 1794. Yale Center for British Art, Paul Mellon Collection.

p. 319 Sailors in a Fight, by John Raphael Smith, 1798. National Maritime Museum, Greenwich, London, Caird Collection.

p. 344 Scenographia Americana: A South West View of the City of New York in North America, by Pierre Charles Canot, 1758-60. Yale Center for British Art, Paul Mellon Collection.

p. 371 Distressed Sailor, by S. W. Fores, 1801. National Maritime Museum, Greenwich, London.

p. 400 Charles Reece Pemberton, by Charles Edward Wagstaff, 1840. National Portrait Gallery, London.

p. 411 Carved whale tooth, by unknown, 1826-30. National Maritime Museum, Greenwich, London.

p. 425 The Dying Sailor, by Thomas Rowlandson (1756-1827). Yale Center for British Art, Paul Mellon Collection.

\section{PLATES}

1. Heaving a Lead, by John Augustus Atkinson, 1807. National Maritime Museum, Greenwich, London.

2. A Married Sailor's Adieu, by Julius Caesar Ibbetson, c.1800. Yale Center for British Art, Paul Mellon Collection.

3. Coast of Sussex, Pushing Off a Boat to a Vessel in Distress, by Joshua Cristall, c.1808. Yale Center for British Art, Presented by Andrew Wyld/W.S. Fine Art Ltd. 
4. Tom Allen (1771-1838), a Greenwich Pensioner, by John Burnet, 1832. National Maritime Museum, Greenwich, London, Caird Collection.

5. The Shipwreck, by Joseph Mallord William Turner, exhibited 1805. (C) Tate/CC-BY-NC-ND 3.0/www.tate.org.uk.

6. The Grosvenor East Indiaman, Capt Coxon Commander Wrecked Augst 4th 1782, on that Part of the Eastern Coast of Africa, Inhabited by the Caffrees ...., by Robert Smirke, 1784. National Maritime Museum, Greenwich, London.

7. Sailors, by John Augustus Atkinson, 1807. National Maritime Museum, Greenwich, London.

8. A View Taken in the Bay of Oaite Peha [Vaitepiha] Otaheite [Tahiti], by William Hodges, 1776. National Maritime Museum, Greenwich, London.

9. The Landing at Tanna [Tana], one of the New Hebrides, by William Hodges, 1775-6. National Maritime Museum, Greenwich, London, Caird Fund.

10. A Sailor Bringing Up His Hammock, Pallas, Jany 75, by Gabriel Bray, 1775. National Maritime Museum, Greenwich, London. Purchased with the assistance of the Society for Nautical Research Macpherson Fund.

11. Seaman Leaning on a Gun on the 'Pallas', by Gabriel Bray, 1775. National Maritime Museum, Greenwich, London. Purchased with the assistance of the Society for Nautical Research Macpherson Fund.

12. The Point of Honour, by George Cruikshank, 1825. National Maritime Museum, Greenwich, London.

13. Portsmouth Point, by Thomas Rowlandson, 1811. National Maritime Museum, Greenwich, London.

14. The Delegates in Counsel or Beggars on Horseback, by S. W. Fores, 1797. National Maritime Museum, Greenwich, London.

15. A death mask of Richard Parker. Baldovio/Hunterian Museum, London/ CC-BY-SA-4.0.

16. Duncan Receiving the Surrender of de Winter at the Battle of Camperdown, 11 October 1797, by Daniel Orme, 1797. National Maritime Museum, Greenwich, London.

17. British Sailors Boarding a Man of War, by John Augustus Atkinson, 1815. National Maritime Museum, Greenwich, London. 
18. The Battle of Trafalgar, by John Christian Schetky, c.1841. Yale Center for British Art, Paul Mellon Collection.

19. Sailors on Board H.M.S. Royal William, by George Henry Harlow, c. 1806. Yale Center for British Art, Paul Mellon Collection.

20. Loss of HMS 'Ramillies', September 1782: Before the Storm Breaks, by Robert Dodd, 1783. National Maritime Museum, Greenwich, London.

21. A Sailor's Return in Peace, by Thomas Stothard, c.1798. National Maritime Museum, Greenwich, London, Caird Fund.

22. The Storeship 'Guardian' in the Channel, Travelling to Botany Bay, Summer 1789, by Benjamin Toddy, 1789. National Maritime Museum, Greenwich, London.

23. Billy Waters, by David Wilkie, 1815. National Maritime Museum, Greenwich, London, Michael Graham-Stewart Slavery Collection. Acquired with the assistance of the Heritage Lottery Fund.

24. Joseph Miller, a Greenwich Pensioner, circa 1832, by John Burnet, 1832. National Maritime Museum, Greenwich, London, Caird Fund.

25. Handyson, a Greenwich Pensioner (b. 1757), by John Burnet, 1832. National Maritime Museum, Greenwich, London.

26. The Fighting Temeraire Tugged to Her Last Berth to Be Broken Up, 1838, by Joseph Mallord William Turner, 1839. NG524/The National Gallery, Turner Bequest, 1856.

27. Greenwich Hospital and Naval Heroes, by Stephen Poyntz Denning after John Burnet. National Maritime Museum, Greenwich, London. 